\title{
Research on Talents Cooperative Innovation Paths in the Coordinated Development for the Beijing-Tianjin-Hebei Region
}

\author{
Liu Tao \\ School of public management \\ Renmin University of China \\ Beijing, China \\ (liutaoruc@ruc.edu.cn)
}

\author{
Bai Haiqi \\ School of public administration \\ Renmin University of China \\ Shijiazhuang, China \\ (bhqzzh123@163.com)
}

\begin{abstract}
Coordinated Development for the Beijing-TianjinHebei Region is a major strategy for economic and social development in the new century. Talents cooperation is the basic guarantee for the strategy implementation. Through literature research and field investigation, this paper analyses the necessity of talents cooperation in the coordinated development process on the historical basis of Beijing-Tianjin-Hebei Region and talentscooperation, Moreover, four paths are to be studied to promote its advancement, namely: talents-education, talents-selection, talents-adoption and talents-retention.
\end{abstract}

Keywords-Coordinated Development for the Beijing-TianjinHebei Region; Talents; Talents Cooperation; Talents Cooperation Path

\section{INTRODUCTION}

The Beijing-Tianjin-Hebei Region, geographically dependent with cultural inheritance and close economic exchanges, are inseparable. However, due to differences in political and administrative division and functional orientation, after the founding of PRC, the developments of these three districts are fragmented. Over thirty years of reform and opening-up, we have witnessed its considerable economic process and social development; however, the level of development is uneven and its structure is irrational. Regional integration has not yet come into full performance. Coordinated development for the Beijing-Tianjin-Hebei Region has become a major issue.

Talents development and cooperation plays a significant role in promoting coordinated development for the BeijingTianjin-Hebei Region, whose top-level design, industrial docking cooperation, urban layout and spatial structure adjustment and optimization, environmental protection, transportation and market integration can't do without talents cooperation. Exploration and innovations for the talents cooperative paths has become the only road to advance the strategy.

\section{REVIEW ON BEIJNG-TIANJIN-Hebei REGION TALENTS COOPERATION}

The development of Beijing-Tianjin-Hebei Region has experienced three stages: industrial base in the Beijing-TianjinTangshan, Beijing-Tianjin-Hebei Regional Integration, as well as Coordinated Development for the Beijing-Tianjin-Hebei Region. From its process, we could find that Initial industrial cooperation gradually extended from human collaboration to policy or even capital collaboration. It goes without any slightest question that talents cooperation for the BeijingTianjin-Hebei Region has also witnessed its own growth from non-strategic, fragmented and local cooperation to strategic, long-term and comprehensive cooperation process. In 1986, Tangshan, Bohai and other 15 cities established the "Bohai Mayor Coordinated Cooperation" coordinately, which has laid the foundation for talents cooperation for the Beijing-TianjinHebei Region. In 2004, the National Development and Reform Commission in Beijing-Tianjin-Hebei region decided to establish a regular high-level mayor joint conference system and organize the economic development strategy seminar. In 2005, they signed the "Talents Development for the BeijingTianjin-Hebei Region and Cooperation Agreement", intending to build the basic framework for talents cooperation. In 2006, Talents Coordinated Development Meeting for BeijingTianjin-Hebei Region was held in Tianjin, while topics around talents exchanges, personnel agency, talents dispatch and other business were discussed. Specific cooperation opinion has formed in discussion.

In 2008, aiming to promote integration of talents cooperation for the Beijing-Tianjin-Hebei Region, "Talents Collaborative Alliance around Bohai Area" was established in Tianjin, which is attached to the alliance mentioned above. Their members include brainpowers in northern talent markets and Tianjin, Dalian (Services and Personnel Exchange Center), Qingdao and other 36 cities. "Talent Collaborative Alliance around Bohai Area" has held a number of personnel exchanges, cooperation and service activities, such as "Bohai Intellectual Exchange Fair", "Regional Talent Recruitment Network in Bohai" "Guidance Training Class for Employment from College Graduates in Tianjin and surrounding area of Bohai" and so on. Up to now, "Talent Collaborative Alliance around 
Bohai Area" has made important contributions as regional cooperation organization services partner connecting most of cities and covering the most extensive area of cooperation for promoting talents cooperation within the region.

In 2011, the Beijing-Tianjin-Hebei Region signed the "Talents Cooperation Framework Agreement for the BeijingTianjin-Hebei Region" in Langfang, committing to share talents market, personnel services, high-level personnel intellectual resources and build a talent innovation and entrepreneurship carrier, establish mutual inclusion of social security system, thus to achieve cooperation in the exchange of talent policy thus to develop a coordinated conference system. Almost the same year, leading group has launched "Coordinated Meeting for Beijing-Tianjin-Hebei Region Talents" in Beijing and adopted the "Charter on Coordinated Talent Conference for the Beijing-Tianjin-Hebei Region" and issued a "Declaration on the Talents Integration of the BeijingTianjin-Hebei Region", which is the very first time at the strategic level to promote regional cooperation from the personnel perspective. At the same year, this regional government has launched a project to promote talent cooperation, signed a "Framework Agreement on Talents for the Beijing-Tianjin-Hebei Region" and proposed that the talent market and personnel services, shared resources and high-level intelligence personnel and other 6 aspects should promote regional talent cooperation comprehensively. In 2013, Premier $\mathrm{Li}$ Keqiang led a new guide to regional cooperation for the Beijing-Tianjin-Hebei Region in his speech in Bohai economic conference. Then, in report on the work of government in 2014 coordinated development for the Beijing-Tianjin-Hebei Region is made clear as a strategy for this region, and the promotion of personnel and labor force mobility has become one of the key regional integration developments.

\section{ThE NECESSITY OF RESEARCH ON TALENT COOPERATION INNOVATION PATHS FOR THE BEIJING-TIANJIN-HEBEI REGION}

Competitions between regions and countries, in the final analysis, rely on the competitions for talents. Talents cooperation in Beijing-Tianjin-Hebei Region has made some advancement such as the level, areas and content. However, there are still some problems: it is not active for Beijing and Tianjin to carry out talents cooperation; the strategic planning of the coordinated development of talents is too coarse; talents cooperation policy convergence is not smooth enough, and talents cooperation paths and areas are not wide enough, etc.

Among such concerns, the brainpower is the key to the innovation and cooperation paths as fundamental objectives. Through field investigation and literature review, this paper assumes that talents innovation and cooperation paths start with four areas, namely: talents-education, talents-selection talentsadoption and talents-retention. Talents-education refers to personnel training; talents-selection refers to recruiting and selection; talents-adoption refers to personnel using and evaluating; and talents-retention refers to policies, measures and treatments to keep talents. In this paper's view, the coordinated talents development directly rely on the effectiveness within four areas mentioned above.

\section{The Construction of New Talents CoOperation PATHS IN COLlabORATICE DEVELOPMENT FOR THE BEIJING-TIANJIN-HEIBEI REGION}

\section{A. Innovation on Talents-Education Cooperation Path}

Talents-education is the starting point and the premise of other three paths. Talents training should take complementary advantages, mutual reciprocity and mutual benefit as principle, and carry out cooperation between colleges and universities actively, thus enhance the vocational and technical colleges academic exchanges and student enrollment training cooperation and foster personnel linkage of party and government and make the cooperation for the joint training of enterprise management, the professionals and the technical with high skill, as well as rural practical talents training cooperation and social work talents training cooperation.

1) Be Active in the Training Cooperation between Universities, Academic Exchanges and Student Enrollment in Vocational Colleges.

It's known to all that Beijing and Tianjin are provided with more elite schools and top teachers. Under the premise of collaborative development, Beijing and Tianjin need to support Hebei in the following areas: strengthening academic exchanges and cooperation with Hebei universities, as well as enrollment in doctoral, post-doctoral training, visiting scholars, undergraduate and graduate admissions policies in continuing education and professional training. Meanwhile, Hebei should take complementary advantages and give full play to vocational and technical schools and support Beijing and Tianjin in vocational personnel training with more educational experienced brain powers.

2) Conduct Party and Government talents Exchange and Cooperation Orderly.

As the maker and executor of development policies, Party and government talents determine efficiency and quality of coordinated development for the throat. The departments concerned should actively carry out the party and government talents assignment like sending some senior party and government talents to take a temporary post to government agencies, talents training counterparts or office. Parties should select talents in accordance with the needs in the exchange activities, and focus on advanced management methods and learn from each other to achieve convergence of different management concepts and policy regimes. Party and government talents should pay more attention to training and academic education; besides, select talents with solid theory foundation and practical ability to participate the academic education in elite schools, or in short-term training courses. In addition, parties should meet training demand and build talents training base by the integration of the education and training resources to obtain more comprehensive training.

\section{3) Emphasis on Enterprise Management talents Training.}

Hebei should regularly send senior business management to the famous schools to participate business management training classes to improve their theoretical level. Meanwhile, the three regional governments should play a leading role in organizing enterprises sub-sector management personnel Forum. Among the three leading enterprises, the leading group 
should have the potential exchange between management staff, and cultivate business management personnel from the practice.

4) Promote Professional And Technical Personnel And Highly Skilled Personnel Training Cooperation Steadily.

In addition to management personnel, the three governments should break the administrative divisions, train the professional and technical personnel with business needs by adopting institutions expertise and top teachers. Besides, the three governments should design talents cooperative training project(specially key projects) and support enterprises to establish the professionals and technical and highly skilled personnel training base thus urge enterprises to conduct on practical training regularly. In addition, the personnel training should be based on training institutions and expertise form various industry clusters and undifferentiated culture.

\section{B. Innovation on Talents-Selection}

Talents-selection is the follow-up stage. This process should be based on regional development needs and need to break the administrative divisions barriers, thus to build talents market-oriented human resources selection and hiring allocation system, the unified professional qualification certification system, a consistent assessment evaluation and incentive mechanism and construct party and government personnel selection and appointment system.

1) Strengthen the construction of the talents market, boost it a fundamental role in the selection part.

Break barriers from talents flow, and the recognition of the unified talents market system combining with infrastructure, information platform and service system should be improved. Developing online talents market, comprehensive regional featured talents market and positive development of professional talents market are the good ways to realize largescale talents flow configuration. Meanwhile, innovative remote management services can be explored, and professional ethics practitioners and service quality training need to be strengthened.

2) Establish a unified professional qualification certification system.

Vocational qualification certificate is an important basis for the selection and its importance determines the level of personnel selection for party and government directly. Research on professional qualification certification system should be reinforced to break the administrative boundaries. Vocational Qualifications departments need build title appraisal committee to develop a unified assessment criteria and procedures for the formation of professional qualification evaluation experts to eliminate duplication of industry professional qualification certificates achieving mutual recognition of professional qualification certificate exchange.

3) Establish and Improve consistent appraisal incentive and evaluation mechanism.

It is to promote the potential of talents and realize the goals for talents choosing with guidance and incentives. According to the overall requirements for the unified and coordinated development of regional classification, business management talents and other talents evaluation system, incentive evaluation mechanism should be improved by establishing organizational performance, by stimulating the vitality of talents and protecting the legitimate rights and interests. It is proper to find talents in the evaluation and assessment stage and select brainpower afterwards.

4) Construct a system of selecting and appointing of party and government talents.

In terms of recruiting civil servants, unified recruit selection policy and admission qualification examination should be developed to achieve mutual recognition of qualifications in interworking. In terms of the promotion of party and government talents, exchange experience and contribution of co-development should be taken as an important condition for the selection and appointment. In terms of open selection of cadres, the selection should be delineated within the BeijingTianjin-Hebei Region, intending to provide more opportunities for the officials in the region, and communications between cities should be strengthened to solve difficult puzzles on selecting cadres off-site openly.

\section{Innovation on Talents-Adoption Cooperation Path}

Talents-Adoption is the ultimate aim and fundamental to previous three stages. The Beijing-Tianjin-Hebei Region should work together with a clear and innovative path to build a broader employment arena, fully mobilize the brainpowers' enthusiasm and real talents.

1) Break the boundaries of administrative divisions, introduce mutual cooperation policy that is suited to three cities.

The regional distribution for talents is more concentrated in Beijing, Tianjin, but scarce in Hebei. Related policy, unified household registration system, and improved social insurance continuation approach should be actively introduced based on the personnel policy of mutual aid and cooperation, which take salary as a lever and talents market as a mobile carrier. Beijing and Tianjin should transfer excessive reserves to Hebei to maximize the talent bonus.

2) Guide the enterprises talents innovation path and establish commission system, industry cooperation system and Cross-industry recommendation system.

Commission system means that when the enterprise itself cannot retain or use someone for a long-term, achieves work goals by resorting to the contract commission. Industry cooperation system refers to establishing talents relations with peers. When the enterprise needs to expand the scale of production, it could adopt borrowing talent resources from peers by resorting to contract. Cross-industry talents recommendation system refers to sharing talents recruitment information and demand. In the recruitment process, if some industry itself does not need someone, they could recommend to other enterprises.

\section{Innovation on Talents-Retention Cooperation Path}

Talents-Retention is a means at the service of talentadoption. The departments concerned should actively work together to create a unified platform for entrepreneurial talent, and build three integrated service system. 
1) Create talent innovation platform and carrier services.

The departments concerned should actively create an integrated interactive platform for innovation and entrepreneurship and improve the "Talent Collaborative Alliance around Bohai Bay Summit" system, host regional talents exchanges, cooperation, service and other activities regularly, building a platform for domestic and international cooperation and innovation talents, suggestions and ideas, discussing issues and share experiences. According to the talents demand conditions and dislocation development, with the principle of complementary advantages, unified planning and functional layout and complete talents innovation and entrepreneurship support should be programming. Equipped with a complete, functional innovation and entrepreneurship incubator platform this region should upgrade and expand a number of Science and Technology Park, Pioneer Park and high-tech parks to attract gifted people to settle down.

2) Promote talents service system for the Beijing-TianjinHebei Region.

The region should coordinately develop unified compensation incentives and reward systems for talents, and explore ways of factors participating in the distribution, including knowledge, technology, management and other production in order to smooth high-level personnel in the political participation. The one who has made outstanding contributions in the economic and social development should be given special political treatment. High-level talents with outstanding contributions should be given special support like housing, schooling for their children and spouse employment and others. Besides, creating an atmosphere of taking care of the talents and supporting them counts much.

\section{SAFEguards ON THE CONSTRUCTION OF New Talent CoOperation Paths in Collaborative DeVElopment of BEIJING-TIANJIN-HEBEI REGION}

Sound organizational structure design, adequate funding and scientific policy system are the basic guarantee for innovative talents cooperation.

Reasonable framework of organization is the main carrier for innovative talents cooperation paths. The Beijing-TianjinHebei Region should negotiate and establish its own center to coordinate talents cooperation comprehensively. Its functions include: formulate talents development strategy properly, improve talents market system vigorously, construct talents public service platform and expand the public service functions of the talents market, talents service and management institutions supervision, etc.

Capital is the source of talents innovation and cooperation. The region's financial sector should be pulled out by the special fund for talents-education, talents-selection, talents-adoption, and talents-retention. The talents capital and special matching funds for regional talents recruitment should be included in the financial budget. According to the financial status of reasonable cost sharing, traditional pattern of "talentseducation by government and talents-selection by enterprise" should be changed. Governments' departments should guide the enterprise funds into talents cooperation and encourage enterprises to support more on talents education, selection, adoption and retention actively; in addition, the Beijing, Tianjin and Hebei integration development opportunity must be seized to absorb social funds extensively.

Scientific and reasonable policy is the lubricant and connector as well to promote talents cooperation for the region. For overall development, regional talents policy system, innovative talents training development mechanism, talents evaluation discovery mechanism, talents selection, appointment mechanism, talents flow allocation mechanism and talents incentive and guarantee mechanism should be coordinately developed. In the process of policy making, the communication and coordination, multiconsultation should be strengthened; moreover, a harmonious environment for the talents policy system should be created.

\section{REFERENCES}

[1] Huzhou municipal Party Committee Organization Department Research Group: "Reserch On Talent Cooperation Model for the Yangtze River Delta", Yangtze River Delta in 2009 (11), page32-34(In Chinese).

[2] Liu Naigang, Liu Yan, "Research on Talent Cooperation for the BeijingTianjin-Hebei Region”, Financial Education and Research, 2012 (4), Page50-51(In Chinese).

[3] Lv Jingjian, Zhao Yunzhong, Yao Yingyuan, Su Yanli, "Path for Cooperation in the West Triangle", Talent Service 2010 (11), Page 50(In Chinese).

[4] Ding Yanli, "Exploration for Talents Demonstration Zone in Hong Kong and Macao", Chinese Talent, 2013 (5), Page21(In Chinese).

[5] Pang Bo, "Exploration on the Circular Economy of Talents Based on the undeveloped areas-Western Areas in China", Department of human resources and social security in Gansu Provincial, China talent development forum in 2012(In Chinese).

[6] Jiang Feng, "Study on the Beijing-Tianjin-Hebei Region Industry Talent Cooperation". Beijing Talent Development Summit Forum Best Paper Anthology in 2011, in June 2011(In Chinese).

[7] Integrate the Work of Human Resources Development and Joint Force of [N], Jiangcheng Daily June 11, 2009, Seventh Edition(In Chinese).

[8] Central Committee and the State Council, "National Long-term Talent Development Program (2010-2020)",June 7, 2010(In Chinese).

[9] Cen Jiafeng, "Reflections on the Construction of Special Zone for Talent Attraction and Retention", Nanning Daily on 14 November 2013(In Chinese). 